\title{
フェナセチン乱用によると思われる腎孟腫瘍の 1 例
}

$\begin{array}{ccccc} & \text { 木 } & \text { 村 } & \text { 光 } & \text { 隆 } \\ & \text { 松 } & \text { 原 } & \text { 正 } & \text { 典 } \\ \text { 杏林大学泌尿器科 } & \text { 諏 } & \text { 訪 } & \text { 純 } & \text { 二 } \\ & \text { 松 } & \text { 山 } & \text { 恭 } & \text { 輔 } \\ & \text { 宾 } & \text { 戸 } & & \text { 悟 } \\ & \text { 千 } & \text { 野 } & \text { 一 } & \text { 郎 }\end{array}$

\section{A CASE OF RENAL PELVIC TUMOR DUE TO PHENACETIN ABUSE}

\author{
Mitsutaka Kimura, Masanori Matsubara, Junji Suwa, Kyosuke Matsuyama, \\ Satoru Shishido and Ichiro Chino \\ Department of Urology, Kyorin University School of Medicine
}

A 46-year-old female has abused phenacetin-containg analgesics because she had severe headache since 1957. In 1978 she was admitted to the Department of Internal Medicine in our hospital because of severe headache. The diagnosis of psychogenic headache, phenacetin nephropathy and granulocytopenia due to analgesic abuse was made. DIP showed left contracted kidney but normal right pyelogram. On April 25, 1983 she visited the Department of Urology in our hospital because of gross hematuria since November 1982. Her total intake of phenacetin was about $4.7 \mathrm{~kg}$ during the 25 year period. Retrograde pyerography revealed a right renal pelvic tumor. Urine cytology showed class IV. Right ureteronephrectomy was performed on July 5, 1983. Histological diagnosis was transitional cell carcinoma, grade 2 , stage $T_{1 a}$. At present, 32 months after the operation, she has no sign of recurrence and metastasis.

\begin{abstract}
要旨：フェナセチン乱用によると思われる腎孟腫瘍の 1 例を経験した。症例は46歳女性. 1957年より頑 固な頭痛出現し, 市販の鎮痛剂を多い時には常用量の $2 \sim 3$ 倍服用するよらになった。1978年頭痛を主 訴に当院内科入院，心因性頭痛，フェナセチン腎症，鎮痛剂常用による白血球減少症の診断を受けた。 当時の排泄性尿路撮影で左萎縮腎が見られたが, 右腎盂像には異常は認められなかった。1982年内科再 入院し, 精査加療中, 同年11月頃より肉眼的血尿出現し, 1983年 4 月 25 日当科依頼された。逆行性腎孟 撮影にて右腎孟に陰影欠損を認め，尿細胞診はClass IV であった。右腎孟腫瘍と診断し，同年 7 月 5 日 右腎尿管全摘術施行した。病理組織診断は移行上皮癌, Grade 2, $\mathrm{pT}_{1} \mathrm{a}$ であった。腎実質は間質性腎炎 の像だった，術後，腎機能低下が見られ BUN $40 \mathrm{mg} / \mathrm{dl}$ 台, Creat $3.0 \mathrm{mg} / \mathrm{dl}$ 台を示したが,一定してい るため, 同年 8 月 11 日退院となった。術後 32 カ月の現在, 腎機能は BUN $47.1 \mathrm{mg} / \mathrm{dl}$, Creat $4.6 \mathrm{mg} / \mathrm{dl}$ とやや上昇傾向を示すが, 一般状態は良好で経過観察中である。尚, 再発, 転移の徵候は見られない。
\end{abstract}

\footnotetext{
緒 言

欧米では,フェナセチン乱用による腎孟腫瘍は数多 く報告されている。しかし，本邦では，現在までに尿 管及び膀脱腫瘍の 1 例 ${ }^{1}$, 膀脱腫瘍の 1 例 ${ }^{2}$ の発生を見 るのみで, 腎孟腫瘍の発生例は見当らない。今回, 我々 はフェナセチン乱用によると思われる腎孟腫崵の 1 例 を経験したので報告する。
}

\author{
症例 \\ 症例：46歳, 女性。 \\ 主訴：肉眼的血尿。 \\ 既往歴：29歳時胃潰瘍を指摘された。 \\ 家族歷：特記すべき事なし。 \\ 現病歴：1957年より頑固な頭痛が出現し，市販の鎮 \\ 痛剂を下記に示す如く連日服用するようになった。
}


1978年頭痛を主訴に当院内科に入院, 各種神経学的検 索をするも異常は認められず，心因性頭痛と診断され た。また、フェナセチン腎症，鎮痛剤常用による白血 球減少も指摘された。当時の排泄性尿路撮影で左萎縮 腎が見られたが，右腎孟像には異常は認められなかっ た（図 1)。その後も鎮痛剂服用を中止できず，1982年 5 月より高血圧も認められるようになり，同内科に再 入院し精査加療した。同年11月より肉眼的血尿が出現 したため近医で受診，止血剂投与されるも軽快しない ため，1983年 4 月25日当科受診した。

鎮痛剤服用歴：1957年～1965年ナロンアンプル® 1 ～ 2 本/日，1966年～1975年ハイグレラン®6～9 錠/ 日，1976年～1982年ナロン錠® 6 錠/日，その他，七デ ス®，ノーシン®等を随時服用していた。服用歷は約 25 年間, フェナセチン推定摂取総量は約 $4.7 \mathrm{~kg}$ であった。

現症：体格栄養中等度。眼球・眼瞼結膜異常なし. 血圧 $150 / 100 \mathrm{mmHg}$. 全身リンパ節触知せず。胸腹部理 学的異常所見なし，神経学的にも異常は認められな かった。

入院時検查成績：血沈 1 時間值 $5 \mathrm{~mm} ， 2$ 時間値 10 $\mathrm{mm}$. 血液一般; RBC $432 \times 10^{4} / \mathrm{mm}^{3}, \mathrm{Hb} 13.0 \mathrm{~g} / \mathrm{dl}$, Ht $37.5 \%$, WBC $2,400 / \mathrm{mm}^{3}$, PBC $21.6 \times 10^{4} / \mathrm{mm}^{3}$. 血液生化学; $\mathrm{Na} 144 \mathrm{mEq} / l, \mathrm{~K} 3.8 \mathrm{mEq} / l, \mathrm{Cl} 107$

図 1 内科入院時排泄性尿路撮影

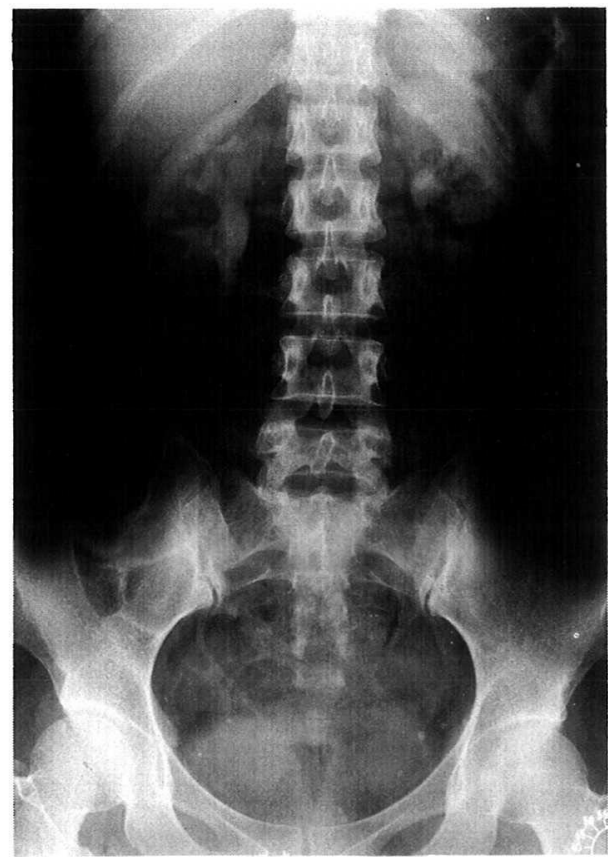

$\mathrm{mEq} / l$, Ca $8.0 \mathrm{mg} / \mathrm{dl}, \mathrm{P} 4.4 \mathrm{mg} / \mathrm{dl}, \mathrm{BUN} 22.1 \mathrm{mg} / \mathrm{dl}$, Creat $1.6 \mathrm{mg} / \mathrm{dl}$, GOT 12mIU, GPT 9mIU, LDH 270 mIU, TP $6.3 \mathrm{~g} / \mathrm{dl}$, CPK 26mIU, CEA $1.2 \mathrm{ng} / \mathrm{ml}$, AFP $6.2 \mathrm{ng} / \mathrm{ml}, \beta_{2}-\mathrm{MG} 3.2 \mathrm{ng} / \mathrm{l}, \mathrm{CCr} 30.1 \mathrm{ml} / \mathrm{min}$. 尿所 見; $\mathrm{pH} 6.5$, 比重 1.013 , 蛋白 $310 \mathrm{mg} / \mathrm{dl}$, 糖 (-), ウ

\section{図 2 逆行性腎盂撮影}

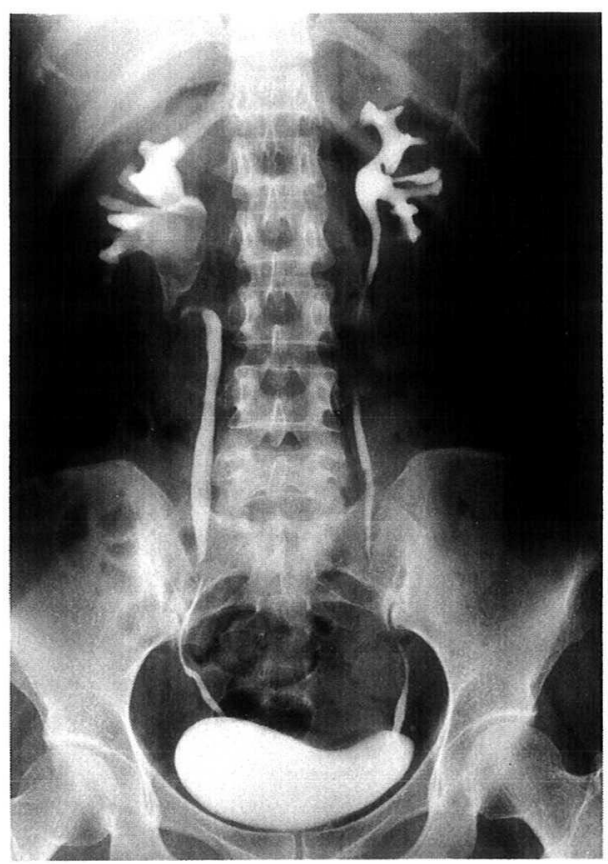

図 3 摘出標本

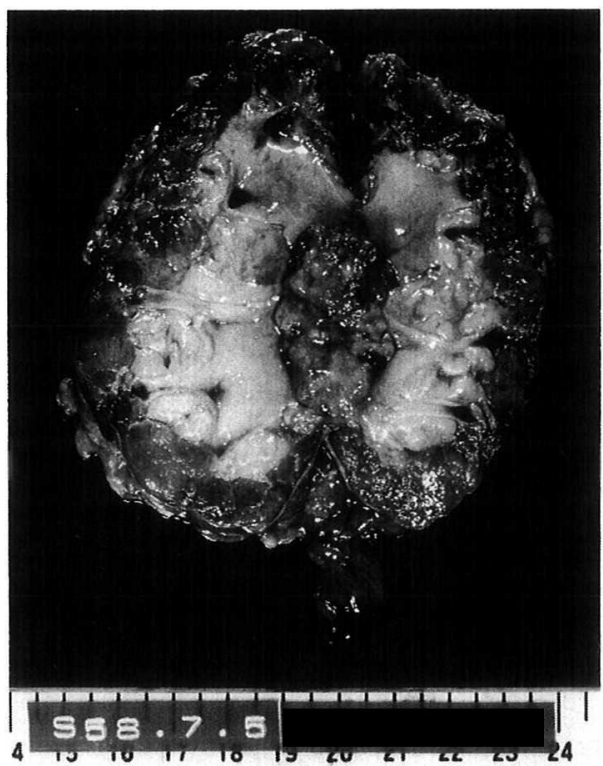


ロビリノーゲン（士），沈椬 $\mathrm{RBC}$ many/HPF, WBC $6 \sim 7 / \mathrm{HPF}$, 細胞診 Class IV. 胸部単純 X-P ; 異常な L.

入院後経過：1983年 5 月 6 日，逆行性腎血撮影施行
し，右腎盎に陰影欠損を認め(㘠 2), 尿細胞診は Class IVであった，CT では右腎血に腫瘍陰影を認めた。後

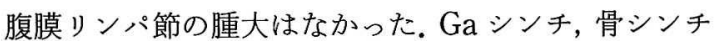
では異常は認められず, 腎シンチ,レノグラムで両側,

図 4 病理組織所見（腫瘍部分）

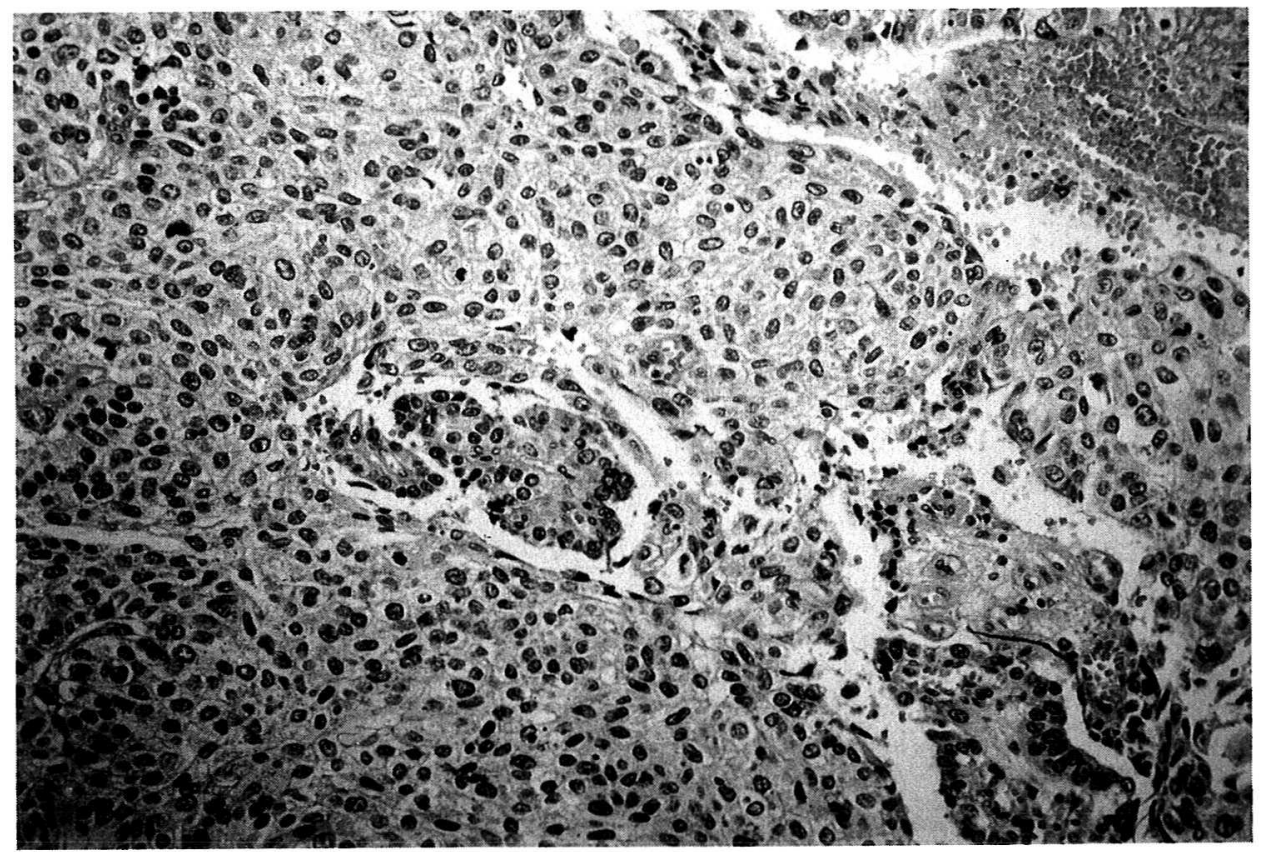

\section{図 5 病理組織所見（腎実質部分）}

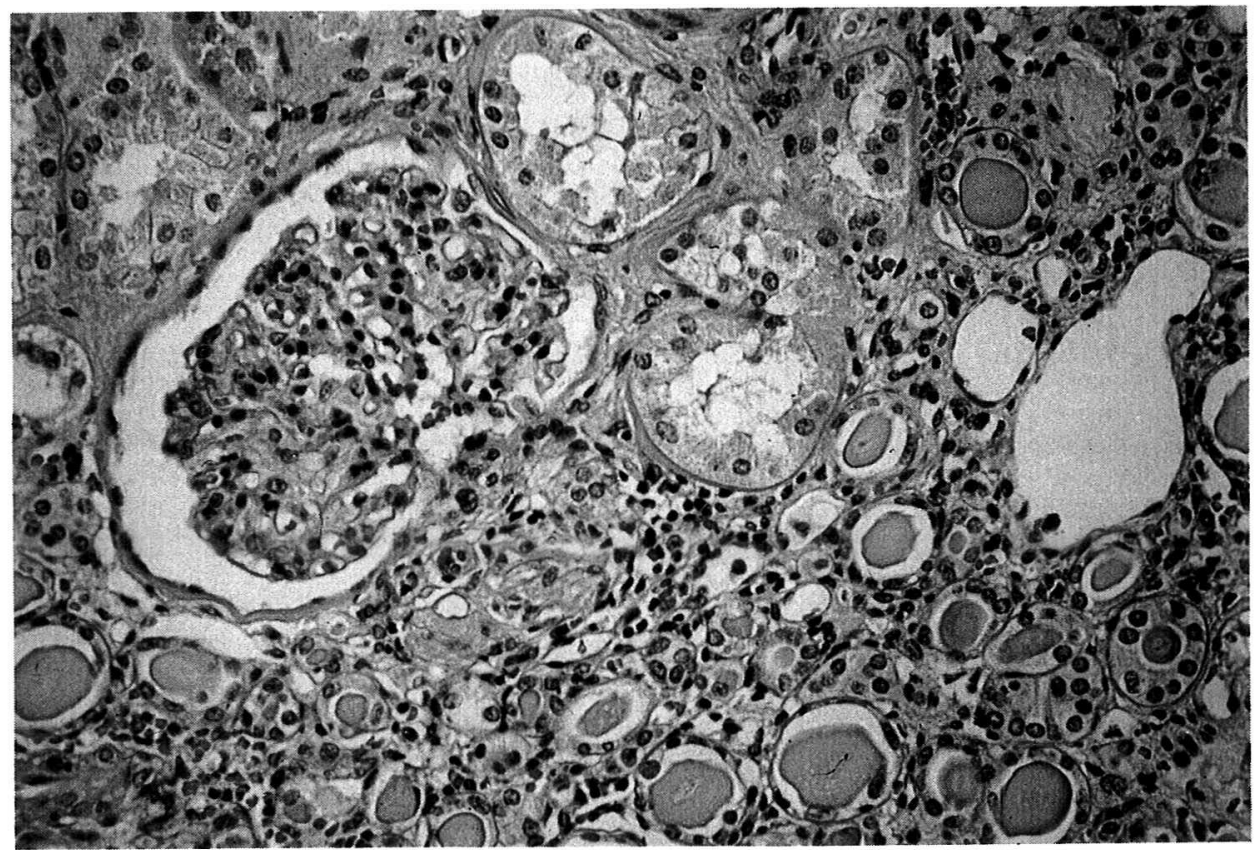


特に左腎の機能低下が認められた。右腎盂腫瘍の診断 で，同年 7 月 5 日，右腎尿管全摘術を施行した。割面 を見ると，腎孟は拡張し，腎孟内に $2.5 \times 1.3 \mathrm{~cm}$, 淡褐 色の乳頭状腫瘤を認めた。 また，腎実質は菲薄化して いた(図 3)。尿管には異常を認めなかった。病理組織 学的診断は移行上皮癌, Grade 2, $\mathrm{pT}_{1} \mathrm{a}$ であった（図 4)。腎実質は間質性腎炎の像だった（図 5 )。術後, 腎機能低下が見られ, BUN $40 \mathrm{mg} / \mathrm{dl}$ 台, Creat $3.0 \mathrm{mg} /$ dl 台を示したが，一定しているため, 同年 8 月11日退 院となった. 1986年 3 月15日現在, 腎機能はBUN 47.1 $\mathrm{mg} / \mathrm{dl}$, Creat $4.6 \mathrm{mg} / \mathrm{dl}$ とやや上昇傾向を示すが, 一 般状態は良好で経過観察中であり，また，再発，転移 の徴候は見られない。

\section{考案 \\ フェナセチンはアニリン系解熱鎮痛剂で臨床的には} 感冒薬として用いられることが多い。欧米では，以前 より主として習慣性頭痛の鎮痛薬として乱用される傾

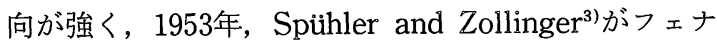
セチンを含有する鎮痛剤の長期大量服用により，腎障 害が発生することを最初に報告して以来, フェナセチ ン腎症として欧米から数多くの報告がある.本邦では, フェナセチン腎症の報告はきわめて稀であり，自験例 はその 1 例で, 1983 年辻ら ${ }^{4)}$ とり 鎮痛剂性腎症の 1 例として報告されている。

フェナセチン含有鎮痛剂乱用による腎孟腫瘍は, 1965年 Hultengren ら ${ }^{5}$ により最初に報告された。欧米 では，その後報告例が増加し，Rathert ら ${ }^{6)}$ は，1965年 から1973年までのフェナセチン含有鎮痛剂乱用による 腎孟腫瘍119例を含む尿路腫瘍124例を集計し，その 75\%に腎乳頭壊死が伴なっていたと報告した。

Mihatsch ら7)はフフェナセチン含有鎮痛剤乱用者は 非乱用者と比較して腎孟腫瘍の発生が77倍高率であっ たと報告している。

Johansson $ら^{8)}$ は,フェナセチン含有鎮痛剂乱用に
よる腎盎腫瘍38例のフェナセチン服用状況を調査して おり, 総服用量は1.5 27kg (平均 $9.1 \mathrm{~kg}$ ), 服用期間は $4 \sim 30$ 年（平均 17 年）であった。フェナセチン含有鎮 痛剂乱用による腎孟腫瘍の特徵としては，通常の腎孟 腫瘍に比較して女性に多く, 若年で, 病理学的に悪性 であり，予後不良とされている899.

フェナセチンの癌原性に関して, Calder (10) $^{\text {は, }}$ フェナセチンの体内メタボライトである N-hydroxyphenacetin を摂取させたラットを用いた実験で，肝に 肝細胞癌, 腎孟に移行上皮癌が発生することを確認し た。また杉安ら ${ }^{11)}$ の動物実験によれば,フェナセチンの 癌原性の標的臓器は鼻腔粘膜及び尿路臓器であると し，尿路系では腎の腎細胞癌，膀胱の移行上皮癌が発 生した。さらに，腎孟上皮の限局性増殖巣が見られた 例があり，腎孟上皮がフェナセチンによる発癌のター ゲットと考えることができると述べている。一方， Macklin ら ${ }^{12)}$ の動物実験では腫瘍発生の増加は認め られなかったと言う報告もある。

本邦に扮けるフェナセチン乱用による尿路腫瘍は， 山本ら ${ }^{1)}$ の多発尿路腫瘍の 1 例及び羽入 ${ }^{2)}$ の膀胱腫 瘍の 1 例の 2 例のみで, 自験例は本邦に抢ける第 3 例 目と思われる。地，腎孟腫瘍の報告例は，我々の調 べ得た範囲では見当たらず，本邦第 1 例目ではないか と推定される。本邦に拈けるフェナセチン乱用による 尿路腫瘍 3 例を表 1 に示した。 3 例全て女性であり, フェナセチン推定摂取量は1.7 9g, 摂取期間 10〜29 年である。また，全例にフェナセチン腎症による腎変 化が認められている。

本邦に执いては，欧米に比べてフェナセチンの乱用 傾向は少ないようである。しかし，臨床的にフェナセ チン乱用による尿路腫瘍の発生が高率であると報告さ れている現在, 本邦に拀いても鎮痛郕, 特に, フェナ セチン服用歴と尿路腫瘍の関係について留意する必要 があろう。

表 1 本邦に拈けるフェナセチン乱用による尿路腫瘍報告例

\begin{tabular}{c|c|c|c|c|c|c}
\hline $\begin{array}{c}\text { 報告 } \\
\text { (年次) }\end{array}$ & 性 & 年齢 & $\begin{array}{c}\text { フェナセチン } \\
\text { 推定摂取量 }\end{array}$ & $\begin{array}{c}\text { フェナセチン } \\
\text { 摂取期間 }\end{array}$ & 発生部位 & 腎 所 見 \\
\hline $\begin{array}{c}\text { 山本ら } \\
(1984)\end{array}$ & 女 & 45 & $1.7-3.2 \mathrm{~kg}$ & 10 年 & $\begin{array}{c}\text { 膀胱 } \\
\text { 尿管 }\end{array}$ & $\begin{array}{c}\text { 腎乳頭壊死, } \\
\text { 間質性腎炎 }\end{array}$ \\
\hline $\begin{array}{c}\text { 羽入ら } \\
(1985)\end{array}$ & 女 & 37 & $9 \mathrm{~kg}$ & 29 年 & 膀胱 & 腎乳頭壊死 \\
\hline 自験例 & 女 & 46 & $4.7 \mathrm{~kg}$ & 25 年 & 腎孟 & 間質性腎炎 \\
\hline
\end{tabular}




\section{結 語}

46歳女性のフェナセチン乱用によると思われる腎孟 腫瘍の 1 例を報告した。

本論文の要旨は, 第49回東部連合総会において発表した。 文献

1）山本憲男, 篠原陽一, 磯山理一郎, 藤沢章二, 北島 敬一, 酒徳治三朗 : フェナセチン長期服用後に腎 乳頭壊死亡多発尿路腫場を合併発生した 1 例. 西 日泌尿，46，873-878，1984.

2) 羽入修吾, 高木隆二, 西山 勉, 関根昭一：フェナ セチン乱用による原発性膀胱腫崵の 1 例. 臨泌, 39, 1037-1039, 1985.

3) Spühler, O. und Zollinger, H.U.: Die chronishe interstitille Nephritis. Z. Klin. Med., 151, 1-50, 1953.

4) 过 正人, 小池透海, 北本 清, 長沢俊彦: 鎮痛剂 性腎症の 1 例. 杏林医学会雑誌, 14, 31-35, 1983.

5) Hultengren, N., Lagergren, C. and Ljungqvist, A.: Carcinoma of the renal papillary necrosis. Acta Chir. Scand., 130, 314-320, 1965.

6) Rathert, P., Melchion, H. and Lutzeyer, W.: Phenacetin: A carcinogen for the urinary tract ? J. Urol., 113, 653-657, 1975.

7) Mihatsch, M.J., Manz, T., Knusli, C., Hofer, H. O., Rist, M., Guetg, R., Rutishauser, G. and
Zollinger, H.U.: Phenacetinabusus III. Maligne Harnwetumoren bei Phenacetinabusus in Basel 1963-1977. Schweiz. med. Wschr., 110, 255-264, 1980.

8) Johansson, S., Angervall, L., Bengtsson, V. and Wahlqvist, L.: Uroepithelial tumors of the renal pelvis associated with abuse of phenacetin-containing analgesics. Cancer, 33 , 743-753, 1974.

9) Bengtsson, U., Johansson, S. and Angervall, L. : Malignancies of the urinary tract and their relation to analgesic abuse. Kideny Int., 13, 107-113, 1978.

10) Calder, I.C., Goss, D.E., Williams, P.J., Funder, C.C., Green, C.R., Ham, K.N. and Tange, J.D. : Neoplasia in the rat induced by N-hydroxyphenacetin, a metabolite of phenacetin. Pathology, 8, 1-6, 1976.

11）杉安浩一郎：フェナセチンの癌原性. 鹿児島大学 医学雑誌, 34, 15-28, 1982.

12) Macklin, A.W. and Szot, R.J.: Eighteen month oral study of aspirin, phenacetin and caffein in C57BL/6 mice. Drug. Chem. Toxicol., 3, 135-163, 1980.

（1986年 4 月 30 日受付） 